\title{
Does Brazil Ethanol Price Affect Brazil Sugar Export? An Indonesians' Perspective
}

\author{
Abdul Wahib Muhaimin \\ Lecturer at Department of Socio-economics, Faculty of Agriculture, \\ University of Brawijaya, Malang, Indonesia \\ Dyana Sari \\ Lecturer at Department of Agribusiness, Faculty of Agriculture, \\ University of Tribhuwana Tunggadewi, Malang, Indonesia
}

\begin{abstract}
The research is financed by The Brawijaya University
Abstract

Besides the biggest ethanol producer, Brazil has been known as the largest sugar producer and exporter. Different from the USA, ethanol from Brazil is made from sugarcane. The sugarcane can also be processed into sugar. Still, ethanol and sugar are not meant to substitute each other, although both are the product of sugarcane. But the apprehension may appear as one of those could be lack of stock. This ultimately leads to an increased price. An increase in sugar price is worthy for Indonesia, the largest sugar importer. The above situation urges a study to find out how far ethanol could alarm sugar export at Brazil as the primary producer for both. The result reveals that ethanol price does not affect Brazil sugar export and even the world sugar price. Brazil sugar export is noninterventionist from that situation. Factors influencing Brazil sugar exports are the country's sugar production and domestic sugar demand. Despite this, world sugar price is affected by world sugar import, whereas world sugar export does not interrupt world sugar price.
\end{abstract}

Keywords: world sugar price, ethanol price, Brazil, world sugar export and import.

DOI: $10.7176 / \mathrm{EJBM} / 11-25-09$

Publication date:September $30^{\text {th }} 2019$

\section{Introduction}

Since Brazil has been known as the world's largest sugar producer, it is a commonplace to ask whether or not ethanol productions affect sugar production in Brazil. This is because ethanol (and sugar) in Brazil is produced from sugarcane, unlike those in the USA as they produce ethanol from corn. In this case, Brazil could have turned sugarcane into complete ethanol, or completely sugar, whenever they wanted.

The above phenomenon needs to be investigated, considering a massive sugar production from Brazil in which no country can compete with it. If Brazil produces more ethanol than sugar, it could be that the world's supply of sugar is disrupted, resulting in changes in world sugar prices. Therefore, a study is urged to answer the question to what extent the production of ethanol affects the production of sugar in Brazil and whether ethanol production affects the production of sugar in Brazil.

Since the 1990s, during the emergence of ethanol as biofuel, many have been concerned regarding the use of ethanol. Intellectuals began to speculate if ethanol would be certainly an important product, then sugarcane would be processed to ethanol than sugar frequently. This also raised a question regarding sugar stock and price. Some argued it would make sugar stock decreased, and it triggered to raise sugar price in the marketplace. Therefore, when does the world sugar stock decrease since Brazil, as the leading sugar exporter, produces more ethanol than sugar-but most importantly, how far the cause of producing more ethanol can effect toward sugar producing?

\section{The Importance of ethanol}

The growth of ethanol consumption has drawn the attention of the public. Although it does not mean to be a total substitution, ethanol can replace the use of oil as fuel. This will encourage Brazil to produce more ethanol; but how far Brazil has been doing for ethanol? Lopez (2012) explains that during the emergence of ethanol in the $1900 \mathrm{~s}$, the sugarcane has been processed more than $75 \%$ while sugar got less than $25 \%$. Since the $2000 \mathrm{~s}$, however, the composition is significantly almost similar, either more ethanol or sugar. There are two important points in this case: (1) price and (2) demand. If the price of ethanol is more appealing than sugar, the production of ethanol will be increased. In addition, if the supply of ethanol is increased, its demand and price will be decreased. The production and supply of sugar will be decreased, increasing its demand. This also leads to an elevated sugar price.

Ethanol market has been emerging to prove how vital fuel as energy for transportation in many countries. As a result, ethanol demand ranges from 99.5 - 100 billion liters in 2011 for the $83.5 \%$ worth of fuel and the rest of non-fuel needs, such as food, beverages, cosmetic and pharmacies (Sucden, 2013). Sucden (2013) claims that world ethanol market is the USA, Brazil, and EU-27 represents about $89-90 \%$ of total world consumption and more than $92 \%$ of world production. 
Supply of ethanol, in fact, is only from two countries which contribute $87.8 \%$ of world ethanol production in 2010, and $87.1 \%$ in 2011 (World Bank, 2013). In 2011, ethanol production from Brazil was 21.1 million liters or $24.9 \%$ of world ethanol consumption as a fuel (RFA, 2012).

Another viewpoint is the characteristics of international sugar price, i.e., low and volatile prices (Fairtrade, 2014). Although the price fluctuates constantly, there is a clear downward trend; this is compared with the situation when Brazil produced $75 \%$ ethanol and sugar $25 \%$ in the 1990 s. Fairtrade (2014) confirms that sugar prices have plummeted 76\% between 1980 and 2000. This implied that if Brazil, as the leading of world sugar exporter, produced more ethanol than sugar, it would make sugar export lesser and sugar price escalated. Another case is an example from Fairtrade (2014). In the early 1980s, the Coca-Cola Company decided to substitute a corn base for sugar in its soft drinks. At the time, Fairtrade notified that Coca-Cola was using 600,000 tons of sugar annually and was the biggest buyer of sugar in the world. Brazil also produced sugar made of $25 \%$ of sugarcane. If at the same time, Coca-Cola requires more supply for sugar, the price of sugar will be increased as the stock was significantly decreased. The above situation occurs in Brazil in which ethanol is produced from sugarcane, while in the USA, ethanol is generated from corn. This condition also applies to corn. In the future, it is predicted that cassava will be popular as it can be processed into ethanol; cassava costs lower than sugarcane or corn. Nobody knows if Brazil would play in cassava, but now, Brazil is the leader of ethanol producers in the world. Recently, ethanol significantly influences not only in the ethanol market but also in the corn market (Lopes, 2012).

It is shown that Brazilian sugar domestic market affects the world sugar market. This illustrates Brazilian sugar demand and supply curves, which signifies that both demand and supply of Brazil sugar domestic market may influence the demand and supply of world sugar.

As the biggest sugar producer, Brazil leads not only the quantity of sugar export but also a price leader. Fortunately, the world sugar price is above sugar producer's cost as Lopes (2012) said that sugarcane field expansion in Brazil's agenda for at least ten years ahead and stock of sugar in the world marketplace had satisfied the future needs. However, what are the factors influencing Brazil sugar export in the world? To what extent those factors affect Brazilian sugar export? Does the price of ethanol influence Brazil to produce more ethanol than sugar by which the sugar export of Brazil will be disturbed? No one argued that ethanol is a by-product of sugar from sugarcane even it is not much, but when all sugarcane is processed into ethanol, is there any fear that ethanol negatively impacts sugar? And will sugar export be affected by ethanol production? Will the price of ethanol influence sugar export of Brazil? These questions demand an answer as sugar is important, and, even more, ethanol is crucial as a source of energy for all people in the world.

\section{Aim of research}

This research examines whether or not the price of ethanol affects sugar export of Brazil. This is to investigate the extent to which ethanol may influence the world sugar market and the extent to which world sugar price will be influenced by world sugar export and import. If the factors are detected, it will raise the awareness of Indonesia regarding the international sugar price as this country is the largest sugar importer.

\section{Methods}

This research utilized a time series data 1982 - 2013 from USDA, World Bank, and Nebraska Government (for ethanol price) with the emphasis on econometrics technique. Using these data can create time series models assuming that whatever forces have influenced the variables known in the recent past will continue into the near future. The model is run by SAS program version 9.0.

The equation concerning this substance is:

$\mathrm{XsBr}=\alpha+\beta \mathrm{PWs}+\gamma \mathrm{QsBr}+\delta \mathrm{DsBr}+\varepsilon \mathrm{PEth}+\zeta \mathrm{XsBr} 1$

Where:

$$
\begin{aligned}
& \mathrm{XsBr}=\text { Brazil the sugar export } \\
& \mathrm{PWs}=\text { Sugar world price } \\
& \mathrm{QsBr}=\text { Brazil sugar production } \\
& \mathrm{DsBr}=\text { Brazil Domestic Demand for sugar } \\
& \mathrm{PEth}=\text { Price of ethanol } \\
& \mathrm{XsBr} 1=\text { Brazil sugar export in the previous year } \\
& \alpha, \beta, \gamma, \delta, \varepsilon, \zeta=\text { parameters }
\end{aligned}
$$

The equation above represents that Brazil sugar export is affected by sugar world price, Brazil sugar production and demand, ethanol price, and Brazil sugar export in the previous year. The last variable is wellknown as a lag equation because many econometric models are dynamic, using lagged variables to incorporate feedback over time. The lag equation in this case is:

$\mathrm{XsBr}=\mathrm{f}(\mathrm{XsBr} 1)$, meaning that Brazil sugar export this year depends on Brazil sugar export last year.

To see how far world sugar price will be influenced by world sugar export and world sugar import, it is essential to build some equations to support this equation: 
$\mathrm{PWs}=\alpha+\beta \mathrm{Xws}+\gamma \mathrm{Mws}$

Where: $\mathrm{PWs}=$ World sugar price

Xws $=$ World sugar export

Mws $=$ World sugar import

$\alpha, \beta, \gamma=$ parameter

Those equations are:

$\mathrm{Xws}=\mathrm{XsBr}+\mathrm{XsTh}+\mathrm{XsAus}+\mathrm{Xso}$

Mws $=$ MwEU + MwIn + MwUSA + Mwso

Where:

Xws $=$ world sugar export

$\mathrm{XsBr}=$ Brazilian sugar export as world largest sugar exporter

$\mathrm{XsTh}=$ Thailand sugar export as second largest sugar exporter

XsAus = Australian sugar export as third largest sugar exporter

Xso $=$ Sugar export from other countries (the rest)

Mws $=$ world sugar import

MwEU = EU's sugar import as world largest sugar importer

MwIn = Indonesian sugar import as second largest sugar importer

MwUSA = USA sugar import as the third largest sugar importer

Mwso = Sugar import from other countries (the rest)

Both equations above are identified equations, which are included in the system but they do not need to get along in the system as they are identified.

\section{RESULT AND DISCUSSION}

Table 01 shows that the result of the equation as a function is good through as the F value reaches 1539.9, which are significant with the level of failure less than $1 \%$. Determination coefficient is 0.997 , meaning that the exogenous variable in the model is explainable (99.7\%). Table 1 also presents that factors influencing Brazil sugar export are Brazil sugar production (QB) and Brazil sugar domestic demand (DsBr); while variable of world sugar price (PWg), world ethanol price (Peth), Brazil sugar export in the previous year (XsBr1) are not significant. The notation of Brazil sugar production $(\mathrm{QgBr})$, which is positive and with failure level of less than $1 \%$, signifies that the higher of Brazil sugar production, the greater sugar export with a regression coefficient of 0.034 .

The notation of Brazil sugar domestic demand, which is negative and significant with the level of failure of less than $1 \%$, explains that the lesser of Brazil sugar domestic demand, the more sugar export in Brazil. The parameters of world sugar price (PWs), ethanol price (Peth) and Brazil sugar export in the previous year is not significant, clarifying that Brazil sugar export is open and liberated without depending on world sugar price, ethanol price, or Brazil sugar export in previous years. In other words, the ethanol price is not affected by Brazil sugar export. Regarding the world price of sugar, the result of this research is shown in Table 02.

Function response of world sugar price is relatively good with an F value of 3.41 with the level of failure less than $5 \%$. The value of determination coefficient determination is 0.2 , signifying that exogenous variables which can be explained are only $20 \%$, while $80 \%$ is explained by other variables not included in the model.

\section{Conclussion}

Factors influencing Brazil sugar export involve Brazil sugar production and Brazil sugar domestic demand. The world ethanol price and world sugar price are not affected by Brazil sugar export. The amount of Brazil sugar export in the previous year also does not affect Brazil sugar export at the moment. Therefore, the price of ethanol does not influence Brazil to produce ethanol more than sugar, and ethanol price is not messed up toward Brazil sugar export. For that reason, there is no fear that ethanol will be a threat to sugar. Brazil sugar production may influence positively towards Brazil sugar export, but this does not apply to ethanol price. Consequently, this does not correlate with ethanol production. Regarding the world sugar price, it is correlated with world sugar import as many countries are on status as sugar importers than sugar exporters. Hence, the world sugar price is not affected by world sugar export, where Brazil is the leader of the sugar exporter. Therefore, Indonesia does not need to worry about the increased price of world sugar as Brazil produces both sugar and ethanol.

\section{Acknowledgement}

The authors express gratitude to Brawijaya University for supporting the conduct of this research.

\section{References}

Anonymousa . (2012). Sugar Industry. Worlds top 10 sugar producing countries - 2011. Available at: http://www.sugarinds.com/2011/06/world-top-10-sugar-producing-countries.html [Accessed 17 May 2017]. Anonymous ${ }^{\mathrm{b}}$. (2012). Agricultural outlook, sugar - OECD - FAO Agricultural Outlook 2011-2020. Available at: 
http://www.agrioutlook.org/document/9/0,3746,en_36774715_36775671_47898825_1_1_1_1,00.html [Accessed 16 May 2017].

Anonymous $^{c}$. (2012). Sugar production from sugarcane. Practical action. Technology challenging poverty. Available at http://practicalaction.org/docs/technical_information_service/sugar_production_from_cane.pdf [Accessed 16 May 2017].

Anonymous ${ }^{\mathrm{d}}$. (2014). Sugar prices fall on adequate stocks. Available at: http://economictimes.indiatimes.com/articleshow/35018840.cms?utm_source=contentofinterest\&utm_medi um $=$ text\&utm_campaign $=$ cppst [Accesses 10 June 2017].

Anonymous $^{\mathrm{e}}$ (2014). Sugar prices falls on weak demand. Available at: http://economictimes.indiatimes.com/markets/commodities/sugar-prices-falls-on-weakdemand/articleshow/33419410.cms [Accessed 10 June 2017].

Anonymous. (2012). Foreign agricultural service. Global Agricultural Information Network (GAIN) Report. Available http://gain.fas.usda.gov/Recent\%20GAIN\%20Publications/Sugar\%20Annual_Jakarta_Indonesia_4-302010.pdf [Accessed 16 May 2017].

Anonymous ${ }^{g}$. (2014). Sugar price and analysis report. Available

at: http://trial.platts.com/sugar?mvr=ppc\&gclid=CPW58qm48L4CFRUVjgod400Ais [Accessed 10 June 2017].

Anonymous $^{\mathrm{h}}$. (1997). Proceedings of the Fiji/FAO 1997 Asia Pacific Sugar Conference FAO Economic and Social Development Department. FAO Corporate Document Repository. Thailand and Vietnam. Available at: http://www.fao.org/docrep/005/X0513E/x0513e24.htm [Accessed 16 April 2017].

Anonymousi . (2012). Agricultural Outlook, Sugar - OECD - FAO Agricultural Outlook 2011-2020. Available at: http://www.agrioutlook.org/document/9/0,3746,en_36774715_36775671_47898825_1_1_1_1,00.html [Accessed 16 May 2012].

Anonymous ${ }^{\mathrm{j}}$. (2012). Sugar production from sugarcane. Practical action. Technology. Challenging poverty. Available at: http://practicalaction.org/docs/technical_information_service/sugar_production_from_cane.pdf [Accessed 16 May 2017].

Fairtrade. (2013). Fairtrade and sugar; Commodity briefing. Available at: www.fairtrade.org.uk/.../2013/.../Fairtrade\%20and\%20Sugar\%20Briefing [Accessed 5 September 2017].

Fairtrade. (2014). Sugar. Fairtrade international. Available at: http://www.fairtrade.net/sugar.html [Accessed 19 June 2017].

Fairtrade. 2014. Minimum price and premium information. Available at: http://www.fairtrade.net/price-andpremium-info.html [Accessed 10 June 2017].

Lopes, A. R. B. C. M. (2012). Brazil - FAO. Brazilian sugar policy. UFPE e Datamétrica. Available at: www.fao.org [Accessed 25 May 2017].

Nebraska Government Website. 2013. Ethanol average rack prices F.O.B. Omaha, Nebraska, 1982-2013. Available at: http://www.neo.ne.gov/stats html'66.html [Accessed 1 February 2017].

RFA. (2012). Accelerating industry innovation. Ethanol industry outlook. Renewable Fuel Association. Available at: http://ethanolrfa.3cdn.net/d4ad995ffb7ae8fbfe_1vm62ypzd.pdf [Accessed 11 June 2017].

Sucden. (2013). Groupe Sucre et Denrees.World sugar production and world ethanol market. Available at: http://www.sucden.com/statistics/10_world-ethanol-market [Accessed 25 May 2017].

Visser, A. (2014). Reference price rise 'to lift retail cost of sugar. Available at: http://www.bdlive.co.za/business/retail/2014/04/10/reference-price-rise-to-lift-retail-cost-of-sugar [Accessed 10 June 2017].

World Bank. (2013). An economic model of Brazil's ethanol-sugar markets and impacts of fuel policies. Available at:

http://econ.worldbank.org/external/default/main?pagePK=64165259\&theSitePK=469372\&piPK=64165421 $\&$ menuPK=64166093\&entityID=000158349_20130628113935\&cid=decresearch [Accessed 11 June 2017].

Table 01. The Response of Brazil Sugar Export Function

\begin{tabular}{lllll}
\hline Variable & Description & Estimated of Parameter & $\mathrm{t}$ Value & $\operatorname{Pr}>|\mathrm{t}|$ \\
\hline $\mathrm{PWs}$ & World sugar price & 8077.232 & 0.51 & 0.6160 \\
\hline $\mathrm{QgBr}$ & Brazil sugar production & 0.964946 & 13.60 & $<.0001$ \\
\hline $\mathrm{DgBr}$ & Brazil sugar demand & -0.94170 & -3.85 & 0.0008 \\
\hline Peth & World ethanol price & -147946 & -0.31 & 0.7584 \\
\hline $\mathrm{XgBr} 1$ & Brazil sugar export last year & 0.034149 & 0.41 & 0.6819 \\
\hline F Value & $=1539.86 ;$ & Pr $>\mathrm{F}=<0.0001 ;$ & R-Square $=0.99689$ &
\end{tabular}

Table 01 shows that the result of the equation as a function is good through as the $\mathrm{F}$ value reaches 1539.9 , which are significant with the level of failure less than $1 \%$. Determination coefficient is 0.997 , meaning that the 
exogenous variable in the model is explainable (99.7\%).

Table 02. The Response of World Sugar Price

\begin{tabular}{|c|c|c|c|c|}
\hline Variable & Description & Estimation of Parameter & t Value & $\operatorname{Pr}>|t|$ \\
\hline $\mathrm{Mw}$ & World Sugar Import & 0.00000154 & 1.12 & 0.2727 \\
\hline $\mathrm{Xw}$ & World Sugar Export & 0.0000000432 & -0.12 & 0.9031 \\
\hline F Value =3.41; & $\operatorname{Pr}>\mathrm{F}:=0.0477$ & R-Square & & \\
\hline
\end{tabular}

Table 02 also shows that factor influencing world sugar price is sugar import, while sugar export does not significantly affect world sugar price. World sugar import influences world sugar price with the level of failure of less than $30 \%$. The notation of world sugar import is positive and significant, indicating that the additional sugar import will increase world sugar price with a regression coefficient of 0.0000054 . The notation of parameter from world sugar export is negative and not significant, meaning that world sugar exports are open and liberated, and, on top of that, it does not depend on world sugar price. 